\title{
Recenzja książki Nieruchomości. Wybrane zagadnienia, red. Joanna Cymermann, Wydawnictwo Politechniki Koszalińskiej, Koszalin 2014, ss. 321
}

Omawiana praca jest wieloautorską monografią poświęconą zagadnieniom ekonomicznym, prawnym i technicznym szeroko rozumianej gospodarki nieruchomościami, dziedziny interdyscyplinarnej, stanowiącej przedmiot badań i analiz ekspertów różnych dziedzin nauki. Gospodarka nieruchomościami w sensie fizycznym dotyczy bezpośrednio powierzchni ziemi, zasobów pod nią oraz nad nią, natomiast w ujęciu prawnym sprowadza się do przywileju korzystania z nieruchomości. Sposób wykorzystania nieruchomości wynika przede wszystkim z konieczności zaspokajania podstawowych potrzeb bytowych ludzi, ale również chęci uzyskania korzyści dodatkowych związanych z wartością nieruchomości. Stąd zarówno regulowanie warunków korzystania z nieruchomości, jak również indywidualne zachowania jej użytkowników mają wymiar ekonomiczny. Dodatkowo każdy z decydentów nieruchomości publicznych determinuje jej przeznaczenie korzyściami społecznymi, jakie przynosi fakt dysponowania wspólną przestrzenią, obok konsekwencji dla środowiska naturalnego.

Tytuł oraz zakres opracowania nawiązują do nieruchomości i miejsca, jakie zajmuje ona w przestrzeni geograficznej, ekonomicznej i społecznej ludzi. Nieruchomość może mieć wymiar prawny, gdy badacz koncentruje się na zagadnieniach własnościowych, formach władania nieruchomością. Ma wymiar techniczny, zwłaszcza gdy przedmiotem dywagacji jest proces inwestycyjny (budowlany) czy też eksploatacja naniesień na gruncie. Ten ostatni aspekt ma już wymiar ekonomiczny, podobnie jak szeroko rozumiane gospodarowanie nieruchomościami. Gospodarowanie w ramach ustanowionych reguł opiera się na zasadach ogólnie rozumianej gospodarności, która zakłada maksymalizację efektów przy ograniczaniu kosztów. Gospodarowanie jest sposobem podejmowania decyzji ekonomicznych, 
więc wszystkie omawiane aspekty, w tym również techniczne i prawne, prowadzą do działania człowieka mającego na celu wybór najlepszej dostępnej możliwości, poprzez porównywanie korzyści i kosztów, co prowadzi do zaspokojenia jego potrzeb związanych z nieruchomościami. Praca stanowi dogłębne studium dotyczące gospodarki nieruchomościami również w kontekście ich wartości. Autorzy dokonali przeglądu literatury w tym zakresie, odnieśli się również do obowiązujących przepisów regulujących omawiane zagadnienia. Zaletą publikacji jest jej szeroki zakres oraz logiczny tok prowadzenia rozważań będących przedmiotem monografii.

Głównym celem, jaki podjęto w monografii, jest wskazanie interdyscyplinarnego charakteru wiedzy z obszaru gospodarki nieruchomościami oraz podkreślenie istotnych problemów i specyfiki zarządzania mieniem pozostającym we władaniu jednostek samorządu terytorialnego i Skarbu Państwa. W tym celu dokonano przeglądu najistotniejszych obszarów i problemów gospodarki nieruchomościami w Polsce, na tle obowiązujących przepisów prawa oraz codziennej dobrej praktyki ekspertów rynku nieruchomości.

Przedłożona do recenzji praca jest monografią dotyczącą wielu istotnych zagadnień związanych z gospodarką nieruchomościami, ujętych w trzech obszarach: zagadnień prawnych, technicznych oraz ekonomicznych. Każdy z rozdziałów zawiera 12 podrozdziałów spójnych tematycznie z trzema głównymi rozdziałami. Monografię rozpoczyna wprowadzenie od Autorów, natomiast wieńczy ją spis literatury, rysunków, tabel oraz załączniki. Monografia stanowi kompendium wiedzy przede wszystkim ekonomicznej i prawniczej na temat szeroko rozumianej gospodarki nieruchomościami oraz praktycznych odniesień do regulacji prawnych i uznanych rozwiązań merytorycznych prezentowanych problemów. W szczególności zostały omówione zagadnienia związane z podstawami prawa cywilnego oraz prawa rzeczowego.

W rozdziale pierwszym zidentyfikowano różnego rodzaju umowy ściśle związane z gospodarką nieruchomościami. Efekty ekonomiczne umów cywilnoprawnych są w przypadku rynku nieruchomości niedoceniane. Dobra umowa najmu stanowi o powodzeniu przedsięwzięcia dochodowego, jakim jest inwestycja w nieruchomości. Pozbawiona wad prawnych umowa kupna-sprzedaży nieruchomości pozwala byłym właścicielom bez obaw uwolnić zamrożony w nieruchomości kapitał, a nabywcom przejąć nieruchomość we władanie z zamiarem osiągania bieżących lub kapitałowych dochodów w przyszłości. Dwa pierwsze rozdziały wspierają wybrane 
zagadnienia podatkowe przedstawione w rozdziale ostatnim. System opłat i podatków związanych z nieruchomościami w Polsce czekają istotne przekształcenia, które odczują bezpośrednio podatnicy, w tym również gospodarstwa domowe. W gospodarkach rozwiniętych funkcjonuje podatek od wartości nieruchomości, w Polsce podatek liczony jest jako iloczyn ustawowej stawki podatkowej i powierzchni nieruchomości. Godzi to w poczucie sprawiedliwości podatkowej i nie pozwala na racjonalną gospodarkę nieruchomościami na terenie gminy chociażby w ujęciu przestrzennym.

Prezentację podstawowych pojęć z obszaru prawa cywilnego i rzeczowego uzupełniają zagadnienia techniczne wraz z problematyką eksploatacji nieruchomości. Ta ostatnia jest domeną zarządzania nieruchomościami, które sprowadza się nie tylko do bieżącego, przede wszystkim technicznego utrzymania nieruchomości, ale również uzasadnionego ekonomicznie inwestowania w nieruchomość środków właściciela. Wybrane zagadnienia z obszaru wiedzy technicznej stanowią część drugą monografii i obejmują cztery rozdziały poświęcone kolejno podstawom budownictwa, a w szczególności klasyfikacji obiektów budowlanych, i zasadom obliczania powierzchni obiektów budowlanych. Z każdym z tych zagadnień zarządca nieruchomości, rzeczoznawca majątkowy czy też pośrednik w obrocie nieruchomościami ma do czynienia zarówno w sferze rozważań teoretycznych, jak również praktycznych. Wspomniane rozdziały uzupełniają rozważania związane z procesem inwestycyjnym, kosztorysowaniem oraz eksploatacją nieruchomości.

Trzecia część monografii obejmuje wybrane zagadnienia szczególnie związane z gospodarowaniem nieruchomościami. To przede wszystkim specyfika gospodarowania publicznymi zasobami nieruchomości, z ich szczególną formą obrotu, szacowania wartości czy ze wspomnianymi zasadami opodatkowania nieruchomości na rzecz gminy. Omówiono w tym miejscu mechanizm użytkowania wieczystego oraz trwałego zarządu nieruchomościami, których właścicielami są Skarb Państwa lub jednostki samorządu terytorialnego. Szczegółowo omówiono również zasady zbywania nieruchomości z zasobu publicznego, w tym preferencyjne zasady zbywania nieruchomości.

Pracę uzupełnia bogaty (170 pozycji) wykaz literatury i aktów prawnych, a także załączniki wspierające zagadnienia omówione w poszczególnych rozdziałach monografii. 
Recenzowana monografia stanowi kompendium wiedzy z zakresu elementarnych problemów dotyczących gospodarowania nieruchomościami, która jest niezbędna zarówno studentom, jak i pracownikom naukowym zajmującym się zagadnieniami gospodarki nieruchomościami. Jest podręcznikiem zalecanym zarówno studentom prawa, jak również kierunków ekonomicznych czy technicznych, w szczególności szeroko rozumianej gospodarki nieruchomościami. Monografia stanowi również ciekawą pozycję literaturową dla praktyków rynku nieruchomości.

Iwona Foryś 